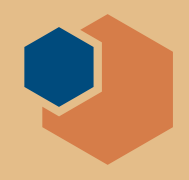

\title{
Governments leverage natural resources in transition to hybrid economy
}

A hybrid resource- and knowledgebased economy has recently evolved as nations rich in natural resources attempt to increase the value of their exports by developing new high-tech industries and products locally, known as in country. This hybrid economy depends both on natural resources and on knowledge resourcesnamely ideas, information, and expertise. The shift away from exporting raw natural resources toward high-tech products is driven by government strategies that can take many forms. For example, different countries have enacted research funding, taxation, investment incentives, and trade regulations. The success of these hybrid economies depends heavily on the methods of implementation, the balance of government and industrial leadership and support received, and the strength of the targeted market. China and South Africa provide interesting examples of two governments that have employed different strategies to promote a transition to this hybrid economy.

China has dominated rare-earth production for nearly two decades and although other sources are beginning to develop, China supplied over $85 \%$ of the world's rare earths in 2012. The Chinese government has begun to consolidate its rare-earth industry and has implemented regulations aimed at eliminating illegal mining operations and protecting the environment. Rare earths - named as critical materials in many countries because of their use in various high-tech and clean-energy technologies - provide a significant opportunity for China to utilize its natural resources to promote a transition toward a hybrid economy. While China does not have an official economic transition policy, their strategy of decreasing rare-earth export quotas will ensure more of these critical materials stay in country for development into more valuable products.
In addition to tightening rare-earth export quotas, the Chinese government has provided significant funding and tax breaks for local and international businesses that wish to set up high-tech manufacturing or research facilities in China. In 2012, China was the world's top clean-energy investor and Bloomberg New Energy Finance predicts that in 2013, China will become the world's largest market for renewable energy. Ready access to such a large market provides further incentive for business ventures. The wind energy market is one example of China's shift from raw resource export to knowledgebased creation of products in countryspecifically wind turbines equipped with neodymium magnets. The investment incentives and relatively easy access to neodymium have fostered rapid growth of the domestic wind market and Chinese companies Goldwind, Sinovel, Guodian United Power, and Sewind were among the top 10 wind suppliers in 2012. While homegrown Chinese companies dominate the domestic market, international wind powerhouses Vestas, General Electric, and Siemens have also entered the Chinese market over the last several years.

South Africa is similarly situated with with the US Geological Survey estimating they hold over $95 \%$ of the world's known platinum group metals (PGM) reserves - key catalyst elements used in catalytic converters and fuel cells. To add value to South Africa's PGM resource and generate local industrial opportunities, the government has provided subsidies to the automotive industry under the Motor Industry Development Program (MIDP) and its 2013 successor, the Automotive Production and Development Program (APDP). These programs established an import/export arrangement where credits earned for exporting locally produced components or vehicles can be used to rebate import duties on components and vehicles. These programs resulted in the establishment of in-country manufacturing for catalytic converters as well as other automotive components and light motor vehicles.

Catalytic converters are South Africa's largest and most revenue-generating automotive component export. South Africa boasts approximately 50 catalytic converter manufacturers and controls about $14 \%$ of the global catalytic converter industry. Over the last 15 years the industry has invested more than $\mathrm{R} \$ 5$ billion (approximately USD \$500 million) to develop catalytic converter production in South Africa. In addition to investments in equipment and plants, significant funds have been spent providing high-tech training and education for South Africans who are employed by the industry - a key part of the transition to a hybrid economy. The development of the catalytic converter industry in South Africa has widely been hailed as a significant success; however, over the course of the MIDP and recent transition to the APDP, the amount of credit earned for catalytic converter exports has dropped. This drop has precipitated an industry shift away from South Africa, and the South African government may have to consider further changes to the catalytic converter incentive scheme under the APDP to ensure a continued market share in the industry.

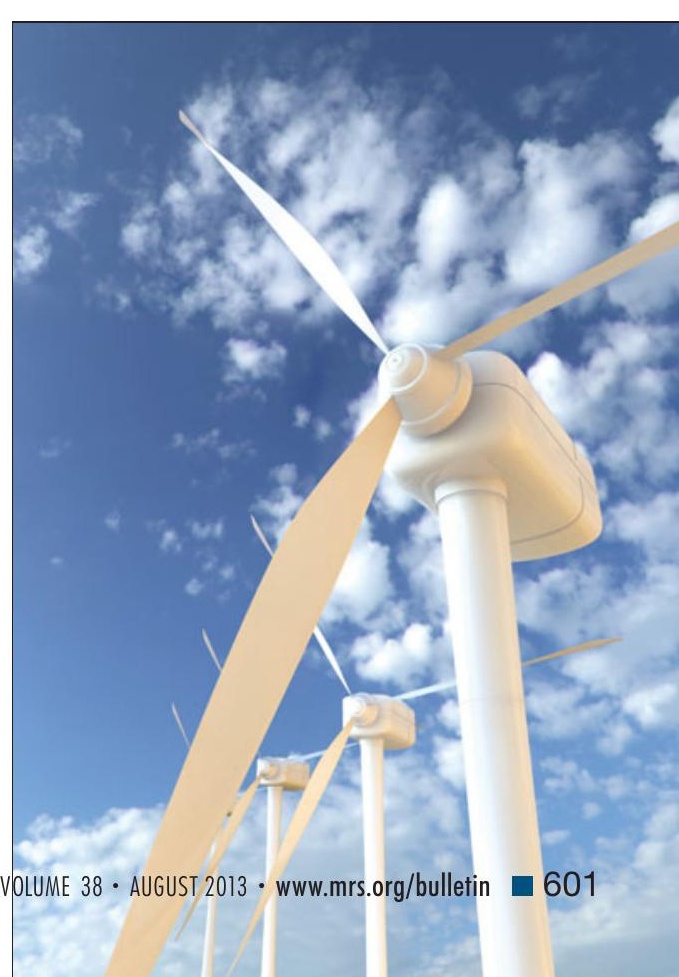


The South African government has also established a 15-year program that seeks to further utilize its PGM resource and develop a hydrogen and fuel-cell industry in country. The first five years of the Hydrogen South Africa (HySA) Program have been focused on attracting international experts from academia and industry to form centers of expertise. This strategy has allowed South Africa to quickly establish competency in current fuel-cell technologies and jump-start a research and development program to innovate new hydrogen and fuel-cell technologies. The second phase of the HySA program began in 2013 and focuses on establishing collaborations with industrial partners. This phase will require significant government incentives for industrial partners to establish PGMand non-PGM-based manufacturing in South Africa. While it is too early in the scope of the HySA program to gauge the industry response and effectiveness of the program, it is nonetheless a good example of a conscious government effort to transition toward a hybrid economy.

As more resource-rich nations make the transition toward a hybrid economy, the global manufacturing and trade landscapes will likely undergo significant changes. One area of international concern stems from the possibility of the develop- ment of a monopoly on a specific material and any products that incorporate that material. Alan Hurd, a Franklin Fellow in the Office of the Science and Technology Adviser to the US Secretary of State, said, "Critical materials are so-named by a country because their utilization is essential to economic or national security, and regional tensions can be exacerbated by a trade imbalance." Hurd said that the transition to a combined resource- and knowledge-based economy "may help the resource-rich countries in the short term, but regional balance must be considered in the long term."

Jennifer A. Nekuda Malik
CSIR to launch titanium pilot plant

www.csir.co.za

$\mathbf{T}$ he Titanium Centre of Competence ( TiCoC), hosted by the CSIR and funded by the Department of Science and Technology, is developing a suite of complementary technologies to help South Africa add value to its vast resources of titanium. Key to this program is the development and commercialization of a novel process for producing the primary titanium metal. The estab- lishment of a small-scale Titanium Pilot Plant on the CSIR campus is an important milestone in this process.

The Titanium Pilot Plant is unique in that it will be able to produce titanium powder at a much lower cost than present imports, making this light metal an economically viable option from which many industries can be created and sustained. South Africa's entire titanium beneficiation strategy depends largely on the success of this pilot plant and its further commercialization.

The launch of the CSIR Titanium Pilot Plant not only unleashes a new era for South African titanium, but also strategically positions South Africa as a key player in the international titanium arena, undoubtedly stimulating further development of various economic sectors with long-term advantages that go into 2020 and beyond.
NRC to help Canadian transportation industry reduce vehicle weight www.nrc-cnrc.gc.ca

A automakers and their suppliers from around the world strive to develop fuel-saving technologies, the National Research Council of Canada (NRC) has announced a new program to help the Canadian transportation industry reduce the weight of cars, trucks, trailers, buses, and trains by developing innovative aluminum technology.

"Canada is a global leader in producing aluminum, and now has the opportunity to lead the world in the transformation of aluminum into parts for lighter weight vehicles," said Michel Dumoulin, General Manager of the Automotive and Surface Transportation portfolio at the National Research Council of Canada.
"This program will support Canadian manufacturers in developing lighter parts and structures that will make our vehicles more fuel-efficient, safer, and environmentally friendly."

The new Lightweighting of Ground Transportation Vehicles Program will see to the development, validation, and deployment of advanced technologies to form aluminum into parts and to assemble and join these parts into next-generation vehicles. The program will enable industry to reduce overall vehicle weight by $10 \%$ within the next eight years.

Before an audience of automakers at the Automotive Parts Manufacturers Association's annual conference in Wind- sor, Ontario, NRC also announced a new research and development consortium that will bring together industry partners from all areas of the manufacturing supply chain to address issues in advanced aluminum shaping, aluminum durability, and parts assembly.

This program and consortium address an immediate industry need as automakers try to find innovative ways to build lighter vehicles and meet strict new fuel efficiency requirements such as the American CAFE (Corporate Average Fuel Economy) regulations to reach 54.5 mpg (4.3 liter per 100 kilometers) average fuel economy by 2025 . Vehicle lightweighting is considered by automakers to have the greatest potential in allowing them to meet these regulations. 